\title{
POPULATION GENETIC STRUCTURE OF SPINY LOBSTERS, Panulirus homarus AND Panulirus ornatus, IN THE INDIAN OCEAN, CORAL TRIANGLE, AND SOUTH CHINA SEA
}

\author{
Gusti Ngurah Permana*\#, Bedjo Slamet"), Bagus Arya Permana**), Ayu Krisna Dewi"*), and \\ Gusti Ngurah Mahardika*) \\ *) Institute for Mariculture Research and Development \\ JI. Br. Gondol, Kec. Gerokgak Kab. Buleleng, Kotak Pos 140, Singaraja 81101, Bali \\ *) Indonesian Biodiversity Research Center, Center of Excellence, Udayana University \\ JI. Sesetan-Markisa 6, Denpasar, Bali, Indonesia
}

(Received 19 September 2018; Final revised 23 January 2019; Accepted 23 January 2019)

\begin{abstract}
Populations of spiny lobsters worldwide are threatened by overfishing, while its supply from aquaculture is currently insufficient to meet the market demand. This current study investigated the genetic structure of two economically important spiny lobsters, P. homarus and P. ornatus sourced from the Indian Ocean and South China Sea. Fragments of the cytochrome oxidase subunit-I (COI) gene of the mitochondrial DNA of 71 P. homarus and 42 P. ornatus collected from 6 and 5 fish landing sites in Indonesia, respectively, were sequenced. Homologous sequences from the Indian Ocean and South China Sea available at GenBank were included in the analysis. No genetic differences were observed in P. ornatus populations from the two geographic regions $\left(x_{S T}=-0.005\right)$ while a diminutive difference was found in the populations of $P$. homarus $\left(x_{S T}=-0.002\right.$ and 0.009$)$. These results, combined with a negative Tajima's $D$ estimates, points to a deficit of nucleotide variation relative to the expectations from the mutation/drift equilibrium. Reconstruction of the phylogeny of P. homarus demonstrates that all Indonesian samples of P. homarus are grouped in one cluster and share the common cluster with GenBank data originated from Taiwan, Vietnam, India, Sri Lanka, Oman, and Iran. The phylogeny of P. ornatus indicates that there are two separated lineages existing in Indonesia.
\end{abstract}

\section{KEYWORDS: Iobster; Panulirus; mitochondrial DNA; COI; nucleotide sequence; phylogeography}

\section{INTRODUCTION}

Spiny lobsters of the genus Panulirus have high economic value as they fetch high prices on the international seafood market, providing a substantial income to fishermen in Africa and Asia (Holthuis, 1991). An estimated 80,000 tons of spiny lobsters are produced annually, most of them wild caught, since aquaculture contributes less than 7\%(Carpenter et al., 2011) from the total production. Spiny lobster aquaculture is based on the collection of naturally settling puerulus larvae in the wild (Jones, 2012). The success of breeding lobster in captivity is limited, because of insufficient knowledge on reproductive biology, physiological requirements of larvae and juveniles, and because of the long planktonic phase and disease prob-

\footnotetext{
\# Correspondence: Institute for Mariculture Research and Development. JI. Br. Gondol, Kec. Gerokgak Kab. Buleleng, Kotak Pos 140, Singaraja 81101, Bali, Indonesia Phone: + 6236292278

E-mail: gustipermana@gmail.com
}

lems of the lobsters (Jones, 2012). Vietnam has become one of the major destinations for pueruli lobsters from Indonesia. P. homarus and P. ornatus are emerging as aquaculture products in the Indo-West Pacific region, especially in Vietnam and Indonesia (Jones, 2012). Spiny lobsters are at risk of overfishing because much of the fishery is largely unregulated, with lobsters of all types, sizes, and conditions, including berried females being caught (Hart, 2009).

Genetic data are needed to rationally manage sustainable fisheries of spiny lobster pueruli and adults. The genetic structure of $P$. homarus has been investigated at various geographical scales (Dao et al., 2013; Farhadi et al., 2013; Lavery et al., 2014). Only slight population structure has been reported from the western and northwestern Indian Ocean (Farhadi et al., 2013), which excluded the southernmost part of the eastern Indian Ocean. Meanwhile, strong genetic differences were reported at the scale of the range of the species in the Indo-Pacific (Farhadi et al., 2013). 
Panulirus homarus rubellus, the subspecies endemic to the southwestern Indian Ocean, belongs to a morphologically and genetically distinct lineage which may deserve full-species status (Lavery et al., 2014), while the population sampled in the Marquesas Islands was represented by a divergent mitochondrial lineage suggesting allopatric isolation. Little information on population genetic structure is available for the Indian Ocean, although a handful of sequences were included in a former publication (Lavery et al., 2014).

The main objective of the present study was to investigate the population genetic structure of both $P$. homarus and $P$. ornatus in the Indian Ocean, the core of the central Indo-West Pacific region. It is expected that the result of this study could be used as a basis to inform fisheries and conservation management. In addition, the information regarding the population genetic structure is also a pre-requisite for selecting aquaculture broodstock of both species.

\section{MATERIAL AND METHODS}

\section{Sampling Area}

P. homarus samples were collected from fishermen at six fish landing sites in Indonesia (Yogyakarta, on the Indian Ocean coast of central Java (site-1); Muncar, on the Indian Ocean coast of eastern Java (site-2); Jembrana, in western Bali (site-3); Lombok; in the Lesser Sunda Islands (site-4); Takalar, of Southern Sulawesi (site-5); and Gorontalo (site-6) (Figure 1). P. ornatus were collected from all the landing sites excluding Yogyakarta (Five sites). The sample sizes are presented in Table 1. The last segment of the last pereiopod of each individual lobster was collected and preserved in absolute ethanol.

DNA was extracted using $10 \%$ Chelexresin (Walsh et al., 1991). A fragment of the cytochrome oxidase 1 (CO1) gene of the mitochondrial DNA was amplified using polymerase chain reaction (PCR) with universal primers LCO1490 and HCO2198 (Folmer et al., 1994). After a successful PCR, nucleotide sequencing was done in both forward and reverse directions using the PCR primers, at the sequencing facility of the University of California, Berkeley. The sequence chromatograms were edited and aligned using ClusthalW in MEGA6 (Tamura et al., 2013). All sequences, trimmed to 612 bp (P. homarus) or 594 bp (P. ornatus) were deposited in GenBank. For P. homarus, previously published sequences from the South China Sea and Indian Ocean were included in the analysis (Lavery et al., 2014; Ptacek et al., 2001; Senevirathna \& Munasinghe, 2013; Senevirathna \& Munasinghe, 2014). For P. ornatus, two sequences from the South
China Sea were added (GenBank nos. HM 446347, JF775573). Genetic diversity parameters, including haplotype diversity, nucleotide diversity, and Tajima's D-statistic (Tajima, 1989) were estimated using DNASP (Librado \& Rozas, 2009). The best substitution models were $\mathrm{T} 92+\mathrm{G}$ for the P. homarus nucleotide-sequence dataset and T92 for the P. ornatus one, both, selected using the "Find best DNA/protein model" option of the MEGa6 software (Tamura et al., 2013). Population-pairwise fixation index between populations ( $\mathrm{X}_{\text {ST }} ;$ T92 model) were estimated using ARLEQUINver 3.5 (Excoffier \& Lischer, 2010; Excoffier et al., 1992). The maximum clade credibility (MCC) phylogeny was inferred in the Bayesian Markov Chain Monte Carlo (MCMC) analysis using the Bayesian Evolutionary Analysis by Sampling Trees (BEAST) software package version 1.7 (Drummond \& Rambaut, 2007; Drummond et al., 2012).

\section{RESULTS AND DISCUSSION}

Haplotype number, haplotype diversity, and nucleotide diversity for each sample of spiny lobsters $P$. homarus and P. ornatus are presented in Table 1. Fragment sizes in P. homarus and P. ornatus were, respectively, 612 bp and $594 \mathrm{bp}$, starting at nucleotide site homologous to, respectively, site no. 40 and site no. 62 of the $\mathrm{CO} 1$ gene in P. ornatus (GenBank no. NC_014854; (Qian et al., 2011).

Both species had high haplotype diversity in all sampling locations. Tajima's neutrality test resulted in generally negative $D$ values in both $P$. homarus and P. ornatus (Table 1), suggesting a deficit of nucleotide variability relative to the expectations from mutation/ drift equilibrium. Pairwise $x_{\text {ST }}$ estimates indicated no geographic structure for P. homarus and P. ornatus across the Indo-Malay archipelago (Table 2). Overall, $x_{\text {ST }}$ was -0.002 for $P$. homarus (using the 382-bp CO1 gene fragment as the marker) and -0.005 for $P$. ornatus at the scale of the Indo-Malay archipelago. It was 0.009 in P. homarus from Indonesia (i.e., South China Sea sample excluded; 612-bp CO1 gene fragment). Neither value was significantly different. Overall $x_{S T}$ over the three main populations of $P$. homarus from the northwestern Indian Ocean, India, Sri Lanka, and Indonesia was $0.057(P<0.001)$.

Reconstruction of the phylogeny of P. homarus is shown in Figure 2. This demonstrates that all Indonesian samples of $P$. homarus are grouped in one cluster and share in, based on GenBank data, the common cluster with lobsters originating from Taiwan, Vietnam, India, Sri Lanka, Oman, and Iran. The data from Madagascar and South Africa form a separate cluster with a posterior probability value of 1 . The 


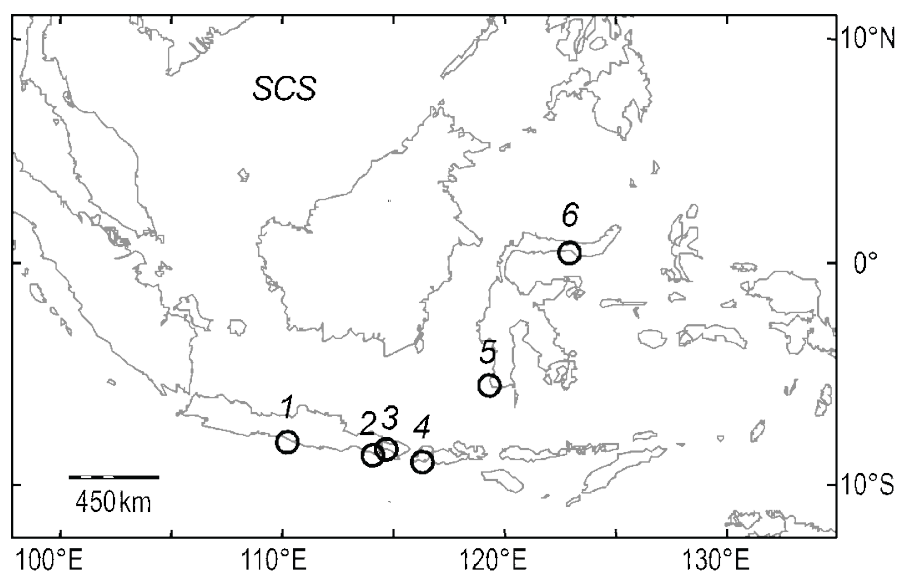

Figure 1. Sampling locations for Panulirus homarus and P. ornatus in the IndoMalay archipelago. (1) Yogyakarta, southern Central Java; (2) Muncar, southern East Java; (3)Jembrana, Bali Strait; (4) Batu Nampar, Lombok; (5) Takalar, South Sulawesi; (6) Gorontalo, Tomini Bay; SCS South China Sea. Background map edited from images downloaded from Digital Vector Maps, San Diego (http://digital-vector-maps. com/).

MCMC tree of P. ornatus data is shown in Figure 3. The tree indicates that there are two separate lineages of $P$. ornatus existing in Indonesia (posterior probability = 1). The first group, represented by four samples from East Java, West Nusa Tenggara, and South Sulawesi, shares in the cluster with Indian sequence data, while the second is with a Pacific isolate.
The spiny lobster genus Panulirus White, 1847 is well known to have a high level of species diversity and wide geographic distribution (Ptacek et al., 2010). Nineteen species have been described, three of which are divided into seven recognized subspecies (Holthuis, 1991; Sarver et al., 1998). The phylogenetic history of this group has been determined. Using two mitochondrial genes of $16 \mathrm{~S}$ rRNA and COI, two

Table 1. Genetic diversity parameters in spiny lobsters P. homarus and P. ornatus from the Indo-Malay archipelago, based on the nucleotide sequences of a fragment of the CO1 gene

\begin{tabular}{|c|c|c|c|c|c|c|}
\hline \multirow{2}{*}{\multicolumn{2}{|c|}{$\begin{array}{c}\text { Species and origin } \\
\text { of sample }\end{array}$}} & \multirow[t]{2}{*}{$\mathbf{N}$} & \multicolumn{4}{|c|}{ Parameters } \\
\hline & & & $\mathrm{h}$ & $H D \pm S D$ & $\Pi \pm S D$ & D (Tajima) \\
\hline \multirow{6}{*}{ P. homarus } & Yogyakarta & 6 & 5 & $0.933 \pm 0.122$ & $0.01667 \pm 0.00262$ & $0.07920 \mathrm{NS}$ \\
\hline & Muncar & 13 & 11 & $0.962 \pm 0.050$ & $0.00842 \pm 0.00096$ & $-1.02340 \mathrm{NS}$ \\
\hline & Jembrana & 17 & 15 & $0.978 \pm 0.031$ & $0.01058 \pm 0.00167$ & $-1.68132 \mathrm{NS}$ \\
\hline & Lombok & 17 & 17 & $1.000 \pm 0.020$ & $0.01238 \pm 0.00208$ & $-1.61781 \mathrm{NS}$ \\
\hline & Takalar & 16 & 14 & $0.983 \pm 0.028$ & $0.01428 \pm 0.00183$ & $-1.07434 \mathrm{NS}$ \\
\hline & Gorontalo & 2 & 2 & $1.000 \pm 0.500$ & $0.00163 \pm 0.00082$ & NA \\
\hline \multicolumn{2}{|l|}{ Total } & 71 & 49 & $0.981 \pm 0.007$ & $0.01190 \pm 0.00096$ & -1.79075 NS \\
\hline \multirow{6}{*}{ P. ornatus } & Muncar & 11 & 9 & $0.945 \pm 0.066$ & $0.00637 \pm 0.00162$ & $-1.72985 \mathrm{NS}$ \\
\hline & Jembrana & 9 & 9 & $1.000 \pm 0.052$ & $0.00608 \pm 0.00069$ & $-0.86291 \mathrm{NS}$ \\
\hline & Lombok & 6 & 5 & $0.933 \pm 0.122$ & $0.00629 \pm 0.00202$ & $-0.88622 \mathrm{NS}$ \\
\hline & Takalar & 10 & 9 & $0.978 \pm 0.054$ & $0.00655 \pm 0.00150$ & $-1.22780 \mathrm{NS}$ \\
\hline & Gorontalo & 4 & 4 & $1.000 \pm 0.177$ & $0.01094 \pm 0.00255$ & $-0.07004 \mathrm{NS}$ \\
\hline & & 40 & 28 & $0.956 \pm 0.023$ & $0.00676 \pm 0.00082$ & $-1.97170 *$ \\
\hline
\end{tabular}

Note: $\quad$ N: sample size; h: number of haplotypes; HD: haplotype diversity; $\circlearrowright$ : nucleotide diversity; D (Tajima): Tajima's (1989) statistic; NA: no computation made because of low sample size 
Table 2. Population-pairwise $x_{S T}$ estimates [16] estimated from partial CO1 gene sequences in rock lobsters $P$. homarus and $P$. ornatus across the Indo-Malay archipelago. For P. homarus, upper row values are $x_{S T}$ estimates based on the 612-bp fragment; lower-row values are $x_{S T}$ estimates based on a 382-bp fragment (see Materials and Methods). Probability of $x_{\text {ST }}$ value under null hypothesis of genetic homogeneity estimated from 1,000 random per mutations under ARLEQUIN [15]. SCSSouth China Sea sample

\begin{tabular}{|c|c|c|c|c|c|c|c|}
\hline \multicolumn{2}{|c|}{ Species, sample origin } & \multicolumn{6}{|c|}{ Sample origin } \\
\hline & & Yogyakarta & East Java & Bali & West Nusa Tenggara & South Sulawesi & Gorontalo \\
\hline \multirow{5}{*}{ P. homarus } & East Java & $0.173^{\mathrm{NS}}$ & & & & & \\
\hline & Bali & $0.106^{\mathrm{NS}}$ & $-0.006^{\mathrm{NS}}$ & & & & \\
\hline & West Nusa Tenggara & $0.012^{\mathrm{NS}}$ & $0.016^{\mathrm{NS}}$ & $-0.014^{\mathrm{NS}}$ & & & \\
\hline & South Sulawesi & $0.000^{\mathrm{NS}}$ & $0.037^{\mathrm{NS}}$ & $-0.003^{\mathrm{NS}}$ & $-0.043^{\mathrm{NS}}$ & & \\
\hline & Gorontalo & $-0.032^{\mathrm{NS}}$ & $-0.077^{\text {NS }}$ & $-0.189^{\mathrm{NS}}$ & $-0.184^{\text {NS }}$ & $-0.146^{\mathrm{NS}}$ & \\
\hline SCS & & $-0.036^{\mathrm{NS}}$ & $0.055^{\mathrm{NS}}$ & $-0.004^{\mathrm{NS}}$ & $-0.050^{\mathrm{NS}}$ & $-0.036^{\mathrm{NS}}$ & $-0.097^{\mathrm{NS}}$ \\
\hline \multirow{4}{*}{ P. ornatus } & Bali & & $0.032^{\mathrm{NS}}$ & & & & \\
\hline & Lombok & - & $-0.052^{\text {NS }}$ & $0.058^{\mathrm{NS}}$ & & & \\
\hline & South Sulawesi & - & $-0.036^{\text {NS }}$ & $0.050^{\mathrm{NS}}$ & $-0.090^{\mathrm{NS}}$ & & \\
\hline & Gorontalo & - & $0.044^{\mathrm{NS}}$ & $0.137^{\mathrm{NS}}$ & $-0.093^{\mathrm{NS}}$ & $-0.019^{\mathrm{NS}}$ & \\
\hline SCS & & & $-0.194^{\text {NS }}$ & $-0.130^{\mathrm{NS}}$ & $-0.092^{\mathrm{NS}}$ & $-0.095^{\mathrm{NS}}$ & $-0.121^{\text {NS }}$ \\
\hline
\end{tabular}

major lineages were found with two groups within Panulirus. The first lineage included all species of Panulirus classified as Groups I and II; the second included all species classified as Groups III and IV. P. homarus and P. ornatus were grouped into group IV (Ptacek et al., 2001). Based on morphologic and genetic data (Lavery et al., 2014) recovered four subspecies of $P$. homarus, i.e. P. homarus rubellus, $P$. homarus brown, $P$. homarus, and $P$. homarus megasculpta. Besides those species, spiny lobsters known to inhabit Indo-West Pacific are P. versicolor, P. polypagus, P. longipes, and P. penicillatus (Humann \& Deloach, 2012).

This is the accordingly published population data from Coral Triangle (CT) area of the most common species P. homarus and P. ornatus (Dao et al., 2013; 2015) This study is to uncover the diversity of $P$. ornatus, the most desired species for the Chinese market (Hart, 2009). The sampling sites were at Southwest corner of world CT.

A proportion of coastal marine Indo-West Pacific species show a marked phylogeographic differentiation on either side of the Indo-Pacific barrier, while others species show little or no differentiation distribution-wide (Carpenter et al., 2011; Hubert et al.,
2012). The latter either inhabit the pelagic environment or have a long pelagic larval phase, for which estimates of genetic differentiation Fst are generally f 0.05 (Fauvelot \& Borsa, 2011). The present results for $P$. homarus and P. ornatus, are finding the population genetic structure of spiny lobsters from the IndoMalay archipelago, conform to the second category as expected for a lobster species with long pelagic larval stage, up to around 180 days (Goldstein et al., 2008; Phillips \& Matsuda, 2011; Dao et al., 2015).

No genetic differences were observed either, at a geographic scale representing a substantial part of the geographic range of $P$. homarus (P. homarus rubellus and the Marquesas were excluded), i.e. from the northwestern Indian Ocean to the South China Sea. A similar conclusion is valid for P. ornatus. This is confirmed by the available mitochondrial sequence dataset which gives no indication that $P$. homarus and $P$. ornatus are geographically structured into distinct populations, from the western Indian Ocean to the Indo-M alay archipelago. The apparent lack of population geographic structure in spiny lobsters across the Indo-M alay archipelago and at the much wider geographical scale of the Indian Ocean and the Indo-Malay archipelago can be explained by their long planktonic life and wide dispersal via ocean currents. 


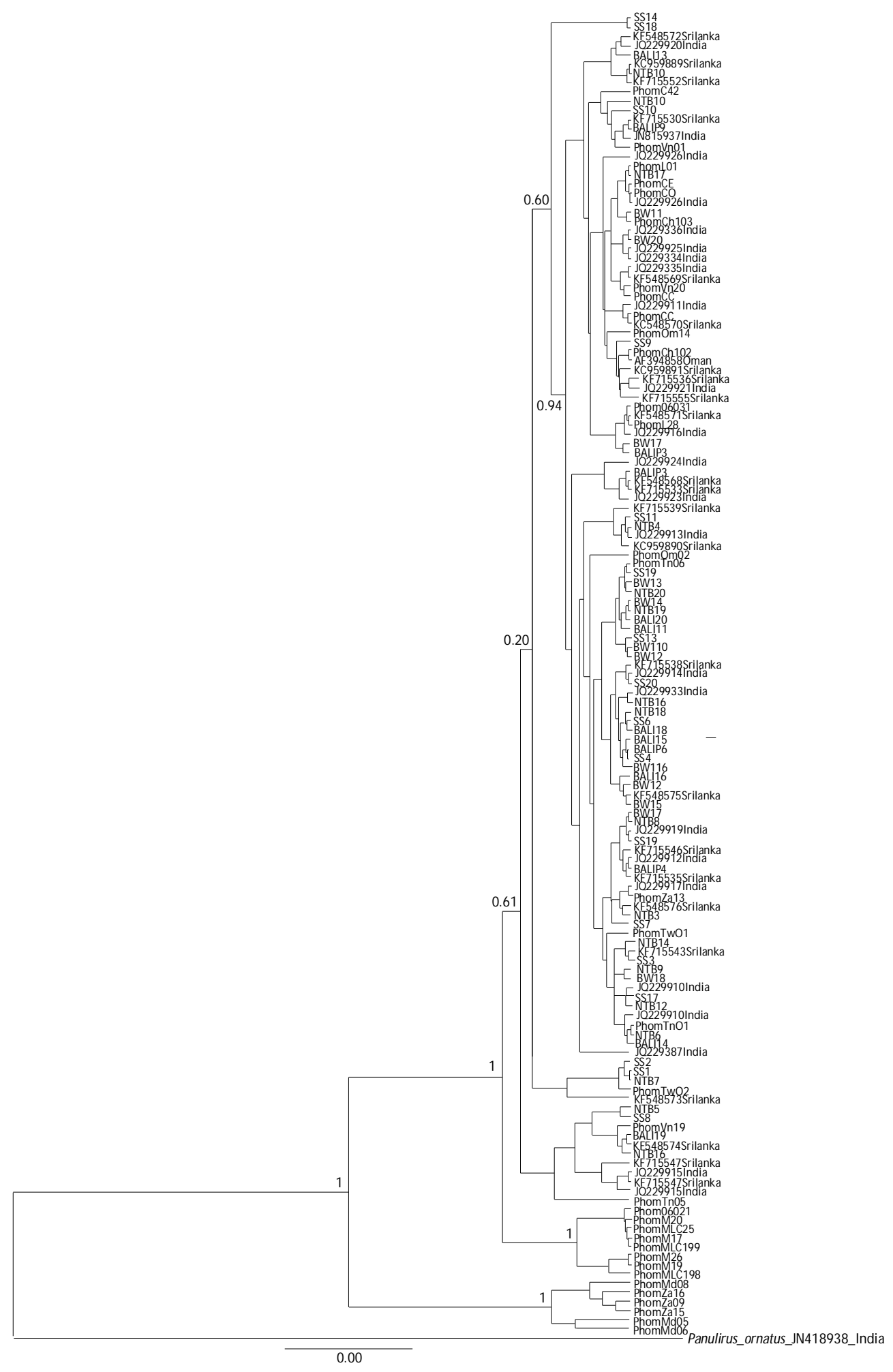

Figure 2. The maximum clade credibility (MCC) phylogeny for mitochondrial COI gene fragment of P. homarus from Indonesia analyzed with sequence data from Western Indian Ocean and South Chinese Sea as previously published (Farhadi et al., 2013; Lavery et al., 2014). The published sequence names are kept as published and added with the country origins. Panulirus ornatus sequence data from India (Acc No. JN418938) was co-analyzed as outgroup. Sequence codes with Bali, NTB, BW, and SS indicate the origin of samples were Bali; West Nusa Tenggara; Banyuwangi, East Java; and South Sulawesi; respectively. Phylogeny was inferred in the Bayesian MCMC analysis using BEAST software. The posterior probability values are shown. 


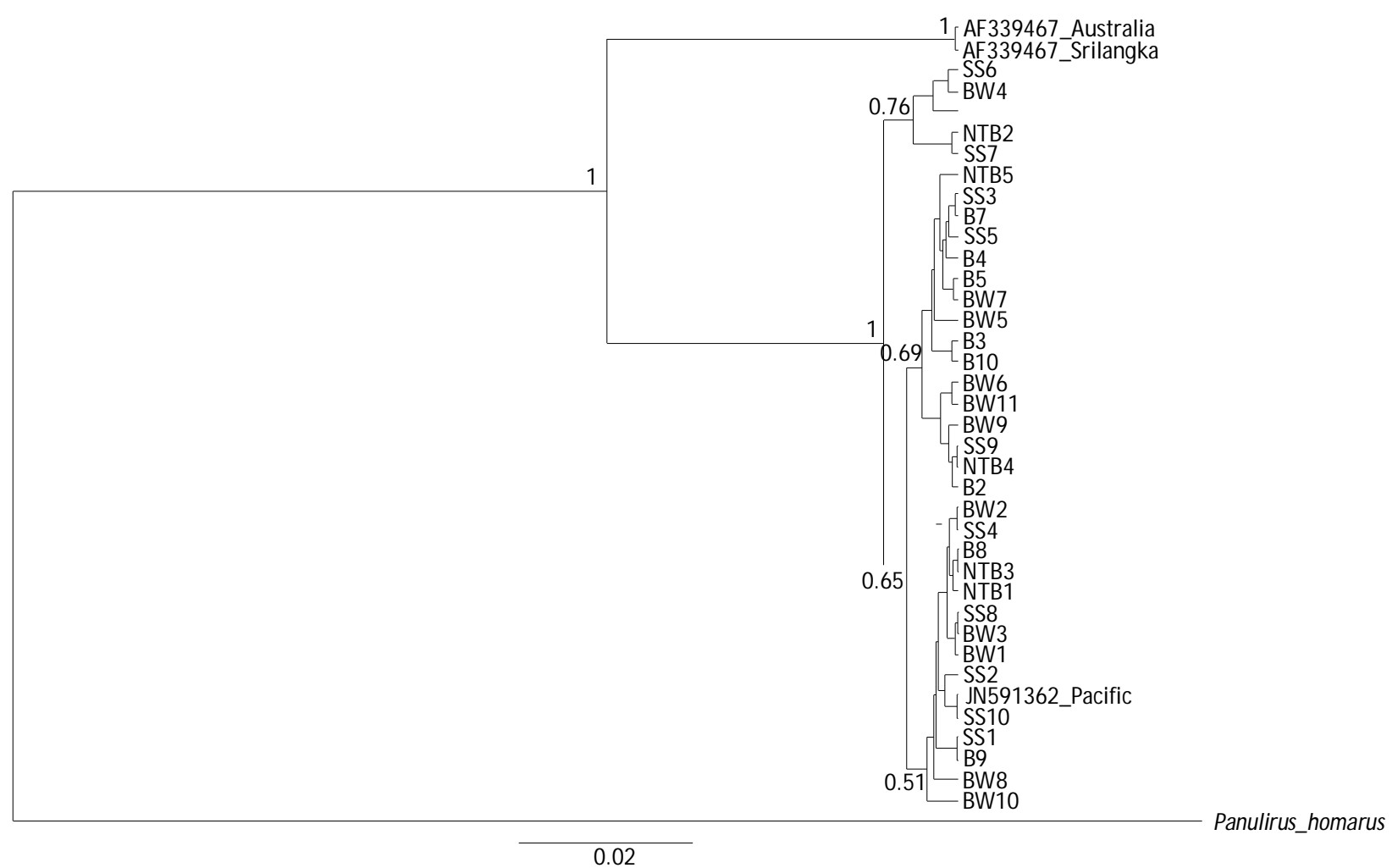

Figure 3. The maximum clade credibility (MCC) phylogeny for mitochondrial COI gene fragment of P. ornatus from Indonesia analyzed with sequence data from some countries in Australia, India, and Sri Lanka available in GenBank. Accession numbers and origin of each secondary data are indicated. Sequence codes and the method to reconstruct the tree are the same as used in Figure 2 . The posterior probability values are shown.

Assuming that the $\mathrm{CO} 1$ gene is a neutral marker of population structure, negative Tajima's $D$ values indicated an excess of rare haplotypes relative to the expectation from the mutation/drift equilibrium (Tajima, 1989). This would be consistent with the recent demographic expansion after a long contraction and consistent with the reduction of coastal habitat in the Indo-Malay region through the Pleistocene (Voris, 2000). Reduction in coastal habitat leading to the Indo-Pacific barrier during periods of lowest sea-level in the Pleistocene has promoted genetic differentiation between Indian and Pacific populations of a variety of species (Carpenter et al., 2011). Although excesses of rare haplotypes may indicate a demographic effect of lower habitat availability on spiny lobsters P. homarus and P. ornatus, no Indian vs. Pacific differentiation was apparent at the mitochondrial locus $\mathrm{CO} 1$. While this may be explained by rapid rehomogenization following the rise in sea level, mediated by long planktonic larval duration, of populations from either side of the Indo-Pacific barrier, one cannot discard the hypothesis of possible rem- nant genetic differentiation in the nuclear genome. Genome scans are warranted, as this may provide new insights into spiny lobster population structure, which the sole mitochondrial marker might not have accessed.

The phylogenetic reconstruction using Bayesian MCMC of P. homarus (Figure 2) supports the notion of allopatric speciation of P. h. rubellus, which inhabits Madagascar and South Africa waters, and P. h. brown in Marquesas is in the central Pacific (Lavery et al., 2014). However, this seems invalid for the other two subspecies, P. h. homarus and P. h. megasculpta. The database sequence data that claimed to be both subspecies are distributed well in a single cluster of our sequence data as well as those published sequences from India and Sri Lanka (Senevirathna \& Munasinghe, 2013; 2014).

The P. ornatus species also follows this pattern, as the limited data from India and the Pacific Ocean also show a monophyletic pattern in the phylogenetic result. However, the evidence of two distinct lineages 
in Indonesia is interesting. The result of this study (Figure 3) also shows that there is a third distinct lineage of P. ornatus, represented by GenBank data from Australia and Sri Lanka (posterior probability = 1). Further population genetic study of this species must be stimulated to clarify this finding.

\section{CONCLUSIONS}

P. homarus and P. ornatus have high haplotype diversity in all sampling locations with no significant population differentiation. Moreover, the Indian Ocean and South China Sea seem to be a single population.

\section{ACKNOWLEDGMENTS}

Funding for this study was from the 2014 budget of the Ministry of Marine and Fisheries Indonesia. Facilities and training for this study were provided by UCLA and the Smithsonian Institution under USAID Grant No: 497-A-00-10-00008-00. The funders had no role in the publication of this manuscript.

\section{REFERENCES}

Carpenter, K.E., Barber, P.H, Crandall, E.D., AblanLagman, M.C.A., Ambariyanto, Mahardika, G.N., Manjaji-Matsumoto, B.M., Juinio-Meñez, M.A., Santos, M.D., Starger, C.J., \& Toha, A.H.A. (2011). Comparative phylogeography of the coral triangle and implications for marine management. Journal of Marine Biology, 14 pp. http://dx.doi.org/10.1155/ 2011/396982.

Dao, H.T., Todd, E.V., \& Jerry, D.R., (2013). Characterization of polymorphic microsatellite loci for the spiny lobster Panulirus spp. and their utility to be applied to other Panulirus lobsters. Conser. Genet. Resour., 5, 43-46.

Dao, H.T., Smith-Keune, C., Wolanski, E., Jones, C.M., $\&$ Jerry, D.R., (2015). Oceanographic currents and local ecological knowledge indicate, and genetics does not refute, a contemporary pattern of larval dispersal for the ornate spiny lobster, Panulirus ornatus in the South-East Asian Archipelago. PLOS ONE, 10, e0124568.

Drummond, A.J. \& Rambaut, A. (2007). BEAST: Bayesian evolutionary analysis by sampling trees. BMC Evolutionary Biology, 7, 214.

Drummond, A.J., Suchard, M.A., Xie, D., \& Rambaut, A. (2012). Bayesian phylogenetics with BEAUti and the BEAST 1.7. M olecular Biology and Evolution, 29, 1969-1973.

Excoffier, L. \& Lischer, H.E. (2010). Arlequin suite ver 3.5: a new series of programs to perform population genetics analyses under Linux and Windows. Molecular Ecology Resources, 10, 564-567.
Excoffier, L., Smouse, P.E., \& Quattro, J.M. (1992). Analysis of molecular variance inferred from metric distances among DNA haplotypes: application to human mitochondrial DNA restriction data. Genetics, 131, 479-491.

Farhadi, A., Farhamand, H., Nematollahi, M.A., Jeffs, A., \& Lavery, S.D. (2013). Mitochondrial DNA population structure of the scalloped lobster Panulirus homarus (Linnaeus 1758) from the West Indian Ocean. ICES Journal of Marine Science, 70, 14911498.

Fauvelot, C. \& Borsa, P. (2011). Patterns of genetic isolation in narrow-barred Spanish mackerel (Scomberomorus commerson) across the Indo-West Pacific. Biological Journal of the Linnean Society, 104, 886-902.

Folmer, O., Black, M., Hoeh, W., Lutz, R., \& Vrijenhoek, R. (1994). DNA primers for amplification of mitochondrial cytochrome c oxidase subunit I from diverse metazoan invertebrates. M olecular Marine Biology and Biotechnology, 3, 294-299.

Goldstein, J.S., Matsuda, H., Takenouchi, T., \& Butler, M.J. (2008). The complete development of larval Caribbean spiny lobster, Panulirus argus, in culture. Journal of Crustacean Biology, 28, 306-327.

Hart, G. (2009). Assessing the South-East Asian tropical lobster supply and major market demands. ACIAR Final Report (FR-2009-06). Australian Center for International Agricultural Research, Canberra, $55 \mathrm{pp}$.

Holthuis, L.B. (1991). Marine lobsters of the world: An annotated and illustrated catalog of species of interest to fisheries known to date. Rome: FAO, $125 \mathrm{pp}$.

Hubert, N., Meyer, C.P., Bruggemann, H.J., Guerin, F., Komeno, R.J., Espiau, B., Causse, R., Williams, J.T., \& Planes, S. (2012). Cryptic diversity in IndoPacific coral-reef fishes revealed by DNA-barcoding provides new support to the center-of-overlap hypothesis. PloS one, 7:e28987.

Humann, P. \& Deloach, N. (2012). Reef creature identification tropical pacific. Jacksonville, Florida, US: New World Publications Inc.

Jones, C. (2012). Cultured aquatic species information programme. Panulirus homarus. FAO Fisheries and Aquaculture Department. Retrieved from http://ww w.fao.o rg/fishery/culturedspecies/ Panulirus_homarus/en; accessed 6 June 2015). Rome, $12 \mathrm{pp}$.

Jones, C.M. (2010). Tropical rock lobster aquaculture development in Vietnam, Indonesia and Australia. Journal of Marine Biology Association India, 52, 304-315. 
Lavery, S.D., Farhadi, A., Farahmand, H., Chan, T.Y., Azhdehakoshpour, A., Thakur, V., \& Jeffs, A.G. (2014). Evolutionary divergence of geographic subspecies within the scalloped spiny lobster Panulirus homarus (Linnaeus 1758). PloS one, 9:e97247.

Librado, P. \& Rozas, J. (2009). DnaSP v5: a software for comprehensive analysis of DNA polymorphism data. Bioinformatics, 25, 1451-1452.

Phillips, B.F. \& Matsuda, H. (2011). A global review of spiny lobster aquaculture. In Fotedar, R. \& Phillips, B.F. (Eds.). Recent advances and new species in aquaculture. Wiley-Blackwell, Hoboken NJ, p. 2284 Wiley-Blackwell, Hoboken NJ.

Ptacek, M.B., Sarver, S.K., Childress, M.J., \& Herrnkind, W.F. (2001). Molecular phylogeny of the spiny lobster genus Panulirus (Decapoda: Palinuridae). Marine and Freshwater Research, 52, 1037-47.

Sarver, S.K., Silberman, J.D., \& Walsh, P.J. (1998). Mitochondrial DNA sequence evidence supporting the recognition of two subspecies or species of the Florida spiny lobster Panulirus argus. Journal of Crustacean Biology, 18(1), 177-186.
Senevirathna, J. \& Munasinghe, D. (2013). Identification of taxonomic status of spiny lobster species in Sri Lanka using DNA barcoding and its implications on fisheries and conservation programs. Tropical Agricultural Research, 25(1), 96-108.

Senevirathna, J. \& Munasinghe, D. (2014). Genetic diversity and population structure of Panulirus homarus populations of Southern Sri Lanka and South India revealed by the mitochondrial COI gene region. International Conference on Food, Biological and M edical Sciences (FBM S-2014). Bangkok.

Tajima, F. (1989). Statistical method for testing the neutral mutation hypothesis by DNA polymorphism. Genetics, 123, 585-595.

Tamura, K., Stecher, G., Peterson, D., Filipski, A., \& Kumar, S. (2013). MEGA6: Molecular evolutionary genetics analysis version 6.0. Molecular Biology and Evolution, 30, 2725-2729.

Voris, H.K. (2000) Maps of Pleistocene sea levels in South East Asia: shorelines, river systems, time durations. Journal of Biogeography, 27, 1153-1167.

Walsh, P.S., M etzger, D.A., \& Higuchi, R. (1991). Chelex 100 as a medium for simple extraction of DNA for PCR-based typing from forensic material. BioTechniques, 10, 506-513. 